\title{
OPPORTUNITIES AND THREATS IN THE POST-ANTIBIOTIC ERA
}

\section{SZANSE I ZAGROŻENIA U SCHYŁKU ERY ANTYBIOTYKOWEJ}

\author{
Marcin Weiner ${ }^{1(\mathrm{~A}, \mathrm{~B}, \mathrm{C}, \mathrm{D}, \mathrm{E}, \mathrm{F}, \mathrm{G})}$
}

\author{
${ }^{1}$ Pope John Paul II State School of Higher Education in Biała Podlaska, Poland
}

Authors' contribution Wkład autorów:

A. Study design/planning zaplanowanie badań

B. Data collection/entry zebranie danych

C. Data analysis/statistics dane - analiza i statystyki D. Data interpretation interpretacja danych E. Preparation of manuscript przygotowanie artykułu F. Literature analysis/search wyszukiwanie $\mathrm{i}$ analiza literatury G. Funds collection zebranie funduszy

\section{Summary}

The following article reviews the issue of antibiotic resistance of microorganisms to meropenem in intensive care units in Ukraine. An increase in meropenem inefficiency against microorganisms in intensive care units has been observed in the last years. The data analysis suggests a significant predominance of gram-negative flora: A. baumannii, P. aeruginosa, Antimicrobial resistance happens when microorganisms change when they are exposed to antibiotics. Then, treatment becomes ineffective and infections persist in the body, increasing the risk of spreading to other persons. The new resistance mechanisms that are emerging and spreading globally cause that the so far applied methods of treatment do not work, threatening the human ability to resist common infectious diseases, which in turn results in prolonged infections or even death. Antimicrobial resistance occurs naturally over time, usually through genetic changes. However, the misuse and overuse of antimicrobials are accelerating this process. It has become common to overuse and misuse antibiotics both in people and animals, which are often prescribed without professional oversight. Antimicrobial resistance is a complex problem that affects all of society and is driven by many interconnected factors. Single, isolated interventions have limited impact. Coordinated action is required to minimise the emergence and spread of antimicrobial resistance.

Keywords: bacteria, resistance, antibiotics, globalisation

\section{Streszczenie}

Ze zjawiskiem antybiotykooporności mamy do czynienia w przypadku gdy bakteria nabierze oporności na dany antybiotyk. Stosowane wówczas leczenie staje się nieskuteczne a obecność samego drobnoustroju w ciele chorego może przyczynić się do jego rozpowszechnienia na inne osoby. Nowe mechanizmy naby wania oporności na antybiotyki sprawiaja, że dotychczasowe sposoby leczenia wielu chorób zakaźnych przestają być skuteczne, czego następstwem są trwające znacznie dłużej zachorowania a nawet śmierć. Zjawisko nabywania oporności nie jest czymś nowym, gdyż wynika z naturalnych właściwości przystosowawczych bakterii jednakże niewłaściwe lub nadużywanie antybiotyków zarówno u ludzi jak i zwierząt znacznie przyspiesza ten proces. Problem antybiotykooporności stał się problemem ogólnoświatowym, dotyczacym wszystkich grup społecznych. Ze względu na złożoność problemu potrzebne są skoordynowane działania gdyż tylko takie mogą przyczynić się do zminimalizowania rozprzestrzeniania tego niekorzystnego zjawiska.

Słowa kluczowe: globalizacja, bakterie, oporność, antybiotyki
Tables: 0

References: 21

Submitted: 2016 Oct 18

Accepted: 2017 Jan 03

\section{Introduction}

Bacteria appeared on Earth about 2.5 billion years ago and acquitted an extraordinary ability to adapt to extremely unfavourable conditions. They can be found in the Antarctic ice, hot springs, and oceanic depths, which are inaccessible even to research robots. They are responsible for many desirable phenomena, for example, lactic or alcoholic fermentation or the synthesis of vitamins. On the other hand, they are accountable for a number of unfavourable processes, such as spoilage of food or rotting. The development of science in the nineteenth century provided much irrefutable evidence that microbes are responsible for causing a number of diseases in humans and animals [1].

\section{The antibiotic era}

The beginning of the antibiotic era is considered to be the year 1928, when a Scottish bacteriologist and physician, Sir Alexander Fleming, went on holiday leaving in his laboratory plates with a medium containing the Staphylococcus aureus strains, Staphylococcus aureus. After returning from vacation, Fleming saw mold 21-500 Biała Podlaska, Poland, e-mail: mpweiner@o2.pl, phone: +48 833449900

Copyright: (C) Pope John Paul II State School of Higher Education in Biała Podlaska, Marcin Weiner. This is an Open Access journal, all articles are distributed under the terms of the Creative Commons Attribution-NonCommercial-ShareAlike 4.0 International (CC BY-NC-SA 4.0) License (http://creativecommons.org/licenses/ by-nc-sa/4.0/), allowing third parties to copy and redistribute the material in any medium or format and to remix, transform, and build upon the material, provided the original work is properly cited and states its license. 
growing on one of the tiles, which inhibited the growth of staph. The fungus on the plate belonged to the species Penicillium notatum; therefore, the mysterious substance secreted by the fungus was called penicillin. The lack of financial resources hindered any research on this substance at that time. However, ten years later, Australian pharmacist Howard Florey and German biochemist Ernst Chain isolated chemically pure penicillin. The following years brought mass-production antibiotic technology and clinical trials initiated by Norman Heatley [3]. In 1941, during the war, penicillin was introduced to treatment on a large-scale, causing a dramatic reduction in deaths of soldiers with infected wounds and bacterial complications. In addition to the use of penicillin on the front of World War II, the substance was also applied in civil medicine to combat a wide variety of infections, so far extremely difficult to fight. The discovery of antibiotics is often considered as one of the ten most significant discoveries of the 20th century, and the substances themselves are referred to as "miracle cures" [2].

The joy associated with the end of war operations coincided with the joy of the then world of scientific discovery of a new weapon against microbes. The three researchers involved in the discovery and use of penicillin were awarded the Nobel Prize in 1945, while Norman Heatley received the honorary doctor's degree in medicine at Oxford University in 1990. While conducting his Nobel lecture, Alexander Fleming talked about what led to discovering penicillin, but at the end warned the world that the improper use of his discovery would lead to a situation where microbes, initially sensitive, become resistant and the situation might get out of control. This message was however wholly ignored at that time [2].

\section{Defining antibiotics}

At this point, it is worth explaining what antibiotics are. In other words, they are substances that either kill bacteria or inhibit their growth. For the first time, the term 'antibiotics' was used by Russian microbiologist Selman Waksman, a later Nobel laureate, the discoverer of two other antibiotics - streptomycin and neomycin. Presently, antibiotics are defined as natural substances, semi-synthetic derivatives and synthetic analogues that, acting selectively on bacterial cell structures, are designed to cause bactericidal or bacteriostatic effects. Antibiotics are divided into groups based on various criteria such as the mode of action, chemical structure or activity spectrum. Some antibiotics cause inhibition of bacterial cell wall synthesis (the presented above penicillin and cephalosporins), whereas others inhibit protein production (chloramphenicol, tetracycline) as well as bacterial RNA and DNA nucleic acids (for example quinolones) [4].

In the 1940s, even small doses of penicillin were sufficient to successfully fight most bacterial infections. Over the years however, the antibiotic dose has been gradually increased until when it has finally been recognised that penicillin has ceased to be effective in infections. It was caused by the defensive reaction of bacteria to antibiotics, the so-called antibiotic resistance.

\section{Bacterial resistance to antibiotics}

It should be emphasised that the phenomenon of antibiotic resistance is not a new one that appeared after the use of antibiotics in medicine. Through evolution, bacteria have developed many mechanisms that defend them against the influence of adverse substances in the surrounding environment, and thus allowing for quick adaptation to adverse changes. It is estimated that until now only about $10 \%$ of antibiotics occurring naturally in nature have been discovered.

So far, five main strategies for bacterial resistance to antibiotics have been found. These include the following:

1. Enzymatic inactivation of the antibiotic by its hydrolysis and chemical modifications, e.g. acetylation,

2. Structural change of the drug interaction site by altering the amino acid sequence of the protein or its chemical modification, e.g. methylation,

3. Replacing the original target with a new molecule, depriving the affinity for the drug,

4. Decreasing permeability of the outer membrane of Gram-negative bacteria

5. Active removal of the drug from the inside of the bacterial cell (5.6).

Resistance to antibiotics in single bacteria would not be a great threat; however, the ability is passed to the next generations on a vertical path as a result of mutation, or a horizontal one, between bacterial cells of the same species, but also those distant from each other in phylogenetic terms. These mechanisms have been used successfully by bacteria for hundreds of thousands of years before man discovered the properties of antibiotics and began to use them on a massive scale in medicine. For example, Canadian researchers isolated bacteria from the bodies of animals preserved in permafrost which have the same genotypic markers that are considered to be the cause of the current spread of antibiotic resistance.

Errors in DNA replication in a bacterial cell called mutations cause that, if the change is unfavourable, the cell dies or its growth is slowed down. However, when the mutation is the result of bacterial adaptation to the 
environment that is unfavourable to one another, the one that is better adapted survives and displaces those that are not mutated from the population. In turn, horizontal gene transfer can occur through conjugation, transformation and transduction. Conjugation occurs through physical contact of two bacteria and the transfer of DNA in the form of a plasmid. Transformation is the process by which a bacterium takes up the genetic material found in the external environment. Transduction occurs with the help of bacteriophages that carry DNA between related bacteria [7].

\section{Staphylococcus aureus resistant to methicillin}

The phenomenon of resistance to penicillin observed in the late 1940s caused that a new search for and synthesis of new antibiotics started. In 1959, methicillin was introduced to clinical practice, but a year later the spread of antibiotic-resistant staphylococci (MRSA) was observed, which is currently one of the most serious threats, especially in the case of nosocomial infections. The introduction of vancomycin in clinical practice temporarily solved the MRSA problem; however, already in 1996, the first MRSA strains resistant to this antibiotic were in Japan. The unprecedented opportunities for travel, including intercontinental one, made the staphylococcus strains resistant to vancomycin transfer both to Europe and the USA. Also, Linezolid, previously regarded as the "last resort" antibiotic in the treatment of MRSA infections, has ceased to be effective because strains that are resistant to it have already appeared.

Until the 1990s, MRSA infections were reported only in hospitalised patients, but over the past 15 years, they have been reported more and more often in out-patient patients or residents of nursing homes with contact with healthcare facilities. Since 2005, there have also been reports of the occurrence of MRSA in farm animals, mainly pigs, young cattle and poultry. In Poland, the share of MRSA in staphylococcal invasive infections in humans is between $20-25 \%$ and in animals at 3-5\% [8-10].

\section{Carbapenemase-producing enterobacteria}

Over the last decade, the primary issue in the field of antibiotic resistance has become intestinal bacilli that produce the so-called carbapenemase, which makes them resistant to carbapenems, the last-resort agents in the treatment of their infections. In addition, they are also resistant to the vast majority of other drugs, and more often there is no therapeutic other option in treating infections caused by these microorganisms. For structural reasons, carbapenemases have been divided into 4 classes, of which carbapenemases A, B and D (11) are the most important.

The first strain of Klebsiella pneumoniae producing class A carbapenemase of the KPC family was isolated in the USA in 1996, and in 1999-2000 in Israel, Greece, Italy and numerous Latin American and Asian countries. In Poland, K. pneumoniae KPC was identified in May 2008 in a hospital in Warsaw. Until the end of 2012, the presence of these bacteria was found in the Holy Cross, Podlaskie, Lubelskie and Silesia Provinces. In total, in the period 2013-2014, there were reported 200 cases of KPC in our country.

Class B carbapenemases (metallo-beta-lactamases) were found in many species of environmental bacteria in the 1980s and in clinical cases have been studied since the 1990s, mainly in the Far East (Japan, South Korea, Taiwan, China ) in Pseudomonas aeruginosa.

A more recent problem in the epidemiology of bacterial infections is the spread of strains of NDM carbapenemase-producing microorganisms (type "New Delhi"). They are commonplace especially in India and other countries of the Indian subcontinent, and numerous studies indicate the existence of their reservoirs in some countries of the Middle East, Africa and the Balkans. Since 2009, there has been an avalanche of reports of NDM bacillus transfer cases to Europe, North America and Australia from the above indicated world regions, which is due to medical tourism, conventional tourism and migration. These reports have become the cause of severe international tensions, going far beyond the field of medicine and epidemiology, and concerning primarily the socio-economic sphere. At present, NDM microbes are the biggest threat in the field of drug resistance in our country. The first case of Congolese origin was recorded in 2011 in Warsaw. At the end of 2012, the epidemic of K. pneumoniae NDM appeared in a hospital in Poznań, with no apparent source. In total, by mid-March 2015, 408 cases were confirmed [12-14]. The literature data indicate that the bla ${ }_{\text {NDM }}$ gene has been transferred from the opportunistic bacteria Acinetobacter baumanii to the Enterobacteriaceae family. The presence of this gene in conjugative plasmids makes the main method of spreading carbapenemases NDM is the horizontal transfer. It should be noted that a high transposition activity of elements containing bla ${ }_{\mathrm{NMD}}(11)$ is also of great importance.

Class D carbapenemases include CHDL enzymes (carbapenem-hydrolysing class D beta-lactamase) found in the 1980s in Acinetobacter. In 2001, a new type of OXA-48 appeared in Turkey, which is mainly related to Klebsiella pneumoniae but also to E. coli and E. cloacae. There has been observed a rapid penetration of these 
bacteria from Turkey and North Africa (Egypt, Morocco) to Europe in recent years, as well as induction of nosocomial infections in France, the Netherlands, Germany and Spain (11).

\section{Enterococci resistant to vancomycin}

An epidemiologically importantgroup are also enterococci resistant to glycopeptide antibiotic and vancomycin (VRE), which, since their appearance in hospitals in the second half of the eighties of the twentieth century, are an increasingly serious problem in the effective treatment of infections caused by these microorganisms. The problem is also increasingly affecting our country, wherein many oncological and hematological centres there are invasive hospital infections, caused both by Enterococcus faecium and Enterococcus faecalis, which have acquired the vancomycin resistance often associated with moving genetic elements ( conjugative transposons, plasmids).

Glycopeptide resistance genes can be located on a chromosome or transposon. The genes that are responsible for the resistance of enterococci to glycopeptides include the following: van A-E.

- van A - showing high resistance to vancomycin, teicoplanin,

- van B - resistant to vancomycin, sensitive to teicoplanin,

- van C - showing constitutive resistance to low concentrations of vancomycin while maintaining sensitivity to teicoplanin,

- van D - moderately resistant to vancomycin and sensitive or low resistant to teicoplanin,

- van E - resistant to vancomycin and teicoplanin.

Currently, the participation of VRE in enterococcal invasive infections in Poland is estimated at approx. 10\%. The reason for additional concerns related to invasive infections caused by enterococci is the emergence of recently resistant strains to the drug of last resort, i.e. linezolid $[15,16]$.

\section{Reasons for the increase in antibiotic resistance}

Until recently, the problem of resistance was thought to affect only nosocomial infections. Presently, it is said to be, first of all, a problem of out-of-hospital infections. The very phenomenon of multi-drug resistance has led to the creation of new definitions in which the pathogens identified above are regarded as deadly threats. MDR strains are defined as those insensitive to three or more groups of antibiotics, XDR strains - strains sensitive to only one or two antibiotics, and strains resistant to all available drugs are included in the PDR group.

The most frequent reasons for the increase in antibiotic resistance indicated in the literature are the overuse and misuse of antibiotics, which results not only in the emergence of resistance, but most of all in its dynamic spread among microorganisms, including the surrounding environment. It has become a standard practice to prescribe antibiotics on demand for people suffering from diseases with viral aetiology, prescribing antibiotics "just in case" as well as (in case of patients) overusing those previously prescribed for other disorders or ceasing taking antibiotics after the initial symptoms disappear. Until now, the doctor who does not prescribe antibiotics has been perceived as one who neglects the patient and does not provide them due attention.

Other reasons for antibiotics acquiring resistance include:

- reducing the supply of new drugs effective in the treatment of infections,

- an increased number of patients with risk factors for infection,

- population ageing (higher numbers of patients in nursing homes and care units and treatment institutions),

- fast and mass transportation of the population and thus globalisation of the problem,

- insufficient use of microbiological diagnostics, exceptionally quick diagnostics and limited access to it in many centres,

- insufficient awareness of the issue in medical professionals, managers in health care and society (insufficient knowledge and awareness),

- excessive and inappropriate use of antibiotics outside human medicine sphere.

\section{Antibiotic resistance as an non-medical problem}

Lately, antibiotics have been increasingly used to fight infectious diseases in animals as well as breeding. Using antibiotics in farm animals is said to bring many beneficial effects as they affect not only their health but also stimulate growth. For this reason, they began to be referred to as antibiotic growth stimulators (ASW). In the same way as in human medicine, in the late 1940s, penicillin was used in veterinary medicine for treating udder infections in dairy cows. Soon, other effects of administering antibiotics were found, not necessarily therapeutic 
ones. In 1946, while conducting studies on streptomycin, it was observed that the addition of this antibiotic to chicken feed increased their body weight gain. Shortly after, in 1949, similar effects of chlorotetracycline were discovered in both chickens and swine and other farm animals. Antibiotics, as preventive feed additives, which eliminated the unfavourable composition of the intestinal microflora, gradually introduced into the breeding practice, increased at the same time bioavailability and the animals receiving them grew much faster. Also in the breeding and veterinary practice, the phenomenon of antibiotic resistance was observed. For this reason, already in 1969, in the so-called Swann's report, there appeared a demand to separate antibiotics into the ones used in breeding and therapy. This led to the withdrawal of penicillin, streptomycin and tetracycline from animal husbandry in many European countries already in 1972-1974.

In recent years, several antibiotic growth promoters have been withdrawn. These include erythromycin, carfenin or oleandromycin. Despite the increasingly restrictive EU regulations that ban the use of antibiotics in animal nutrition, these substances are successfully used in the USA, South America, Russia and China. Currently, antibiotics are used on a massive scale in the breeding of aquatic animals, especially fish, mussels and shrimps, as well as in bee breeding. Fish farms, established on the coastal, saline waters of many countries of South America and Asia cover large areas and run intensive breeding businesses. On farms designed for prophylactic purposes, vast amounts of antibiotics are consumed, which are added directly to the water. This causes depositing of these substances in the water as well as bottom sediments. A large part of these substances is transferred to considerable distances due to sea currents. It is estimated that $1500 \mathrm{x}$ more antibiotic is used to produce 1 ton of salmon in South America than in Norway or Canada [17-20].

\section{Antibiotics in the environment}

Although in clinical practice the metabolic changes of antibiotics, their bioavailability and impact on the human body have been described, there has been little research so far on what happens to antibiotics once they have been released into the environment. The appearance of antibiotics in soil or water causes changes in the composition of the microflora of a given environment. In this way, the biological balance of a given ecosystem is disturbed, which leads to disturbances in the circulation cycles in many natural elements, including biogenic ones. Another danger is the presence of antibiotics in products and raw materials coming from different animals and consumed by humans. An immediate threat consists in triggering allergic reactions (e.g. to penicillin), carcinogenic ones (to oxytetracycline), nephropathy (gentamicin) and their effects on the microflora in the human digestive tract (immune disorders, bad vitamin, impaired absorption).

\section{Where are we heading to?}

To reduce the problem of antibiotic resistance that is increasingly commonplace in microorganisms, it is necessary to take global actions. Due to the importance of the issue, the fight against it has become a priority for organisations like the European Commission, the World Health Organization, the European Parliament, the Food and Drug Administration (FDA) and the Centre of Diseases Control and Prevention (CDC). As regards public health, drug resistance, in addition to combating influenza, HIV and tuberculosis, has become a priority. In Poland, the National Antibiotic Protection Programme was successfully implemented in the years 2011-2015. Also, several days ago, the Minister of Health accepted the new edition of the Programme for the years 20162020. Few people know that November 18 is the European Antibiotic Awareness Day, which aims to educate the public about their effects and risks that may arise from the inappropriate use of antibiotics and the danger of resistance build-up. As the results of research carried out by the National Medicines Institute show, there is an urgent need of implementing educational measures, which may indicate that Poland is at the forefront of the countries excessively prescribing antibiotics for cold, flu or a cough. As many as 50\% of Poles think that antibiotics are effective in treating influenza, 38\% assume that they also treat common cold and as many as $63 \%$ think that they fight viruses effectively [21].

The emergence of strains resistant to all antibiotics used so far heralds an inevitable decline of the antibiotic era and becomes a warning signal that should not be underestimated. In the last 20 years, only two new antibiotics have been created. Bearing in mind the cost of their production, including the need to perform many clinical trials for years, mathematical modelling or the need to search for organisms that produce natural antibiotics and come from extreme environments (sea depths, thermal waters), pharmaceutical companies are primarily interested in the production of over-the-counter drugs, whose consumption doubles each year becoming a net profit. The only thing that can be done is to rationally use the antibiotics that are currently available so that they can be successfully used by future generations. Therefore, before we reach for the antibiotic ourselves, let's think whether it is worth it. One can be young, beautiful and rich, but being healthy is the biggest asset. 


\section{References:}

1. Baron S. Medical Microbiology. 4th edition. University of Texas Medical Branch at Galveston; 1996.

2. Fleming A. Penicillin. Nobel Lecture, December 11, 1945 [cited 2016 Oct 18]. Available from: https://www. nobelprize.org/nobel_prizes/medicine/laureates/1945/fleming-lecture.pdf

3. Harris H. Howard Florey and the development of penicillin. Notes Rec. R. Soc. Lond. 1999, 53: 243-252.

4. Cuddy PG. Antibiotic classification: implications for drug selection. Crit Care Nurs Q. 1997 Nov, 20(3): 89-102.

5. Pulcini C, Mainardi JL. Antimicrobial stewardship: an international emergency. Clin Microbiol Infect 2014; 20: 947-948. https://doi.org/10.1111/1469-0691.12791

6. Antimicrobial resistance: global report on surveillance. WHO, 2014.

7. Laxminarayan R, Duse A, Wattal C, Zaidi AK, Wertheim HF, Sumpradit N, et al. Antibiotic resistance-the need for global solutions. Lancet Infect Dis. 2013 Dec; 13(12): 1057-98. https://doi.org/10.1016/S14733099(13)70318-9

8. Grundmann H, Schouls LM, Aanensen DM, Pluister GN, Tami A, Chlebowicz M, et al. The dynamic changes of dominant clones of Staphylococcus aureus causing bloodstream infections in the European region: results of a second structured survey. Euro Surveill 2014 Dec 11; 19(49): pii=20987.

9. Krupa P, Bystroń J, Bania J, Podkowik M, Empel J, Mroczkowska A. Genotypes and oxacillin resistance of Staphylococcus aureus from chicken and chicken meat in Poland. Poult Sci. 2014 Dec; 93(12): 3179-86. https://doi.org/10.3382/ps.2014-04321

10. Deurenberg RH, Stobberingh EE. The evaluation of Staphylococcus aureus Infection, Genetics and Evolution. 2008; 8: 747-63. https//doi.org/10.1128/JCM.00820-09

11. Nikonorow E, Baraniak A, Gniadkowski M. Oporność bakterii z rodziny Enterobacteriaceae na antybiotyki beta-laktamowe wynikająca z wytwarzania beta-laktamaz. Post Mikrobiol. 2013; 52(3): 261-271.

12. Glasner C, Albiger B, Buist G, Tambić Andrasević A, Canton R, Carmeli Y, et al. Carbapenemase-producing Enterobacteriaceae in Europe: a survey among national experts from 39 countries, February 2013. Euro Surveill. 2013 Jul 11;18(28): pii=20972.

13. Bush K. P Proliferation and significance of clinically relevant $\beta$-lactamases. Ann N Y Acad Sci. 2013;1277: 8490. https://doi.org/10.1111/nyas.12023

14. Canton R, Akova M, Carmeli Y, Giske CG, Glupczynski Y, Gniadkowski M, et al. Rapid evolution and spread of carbapenemases among Enterobacteriaceae in Europe Clin Microbiol Infect. 2012 May;18(5):413-431. https://doi.org/10.1111/j.1469-0691.2012.03821.x

15. Arias CA, Murray BE. The rise of the Enterococcus: beyond vancomycin resistance. Nat Rev. Microbiol. 2012 Mar 16; 10(4): 266-78. https://doi.org/10.1038/nrmicro2761

16. Wardal E, Markowska K, Zabicka D, Wróblewska M, Giemza M, Mik E, et al. Molecular analysis of vanA outbreak of Enterococcus faecium in two Warsaw hospitals: the importance of mobile genetic elements. Biomed Res Int. 2014; 2014: http://dx.doi.org/10.1155/2014/575367

17. Van den Bogaard AE, Stobberingh EE. Epidemiology of resistance to antibiotics. Links between animals and humans. Int J Antimicrob Agents 2000; 14: 327-335.

18. Wegener HC. Antibiotics in animal feed and their role in resistance development. Curr Opin Microbiol 2003; 6: 439-445.

19. Bates J, Jordens JZ, Griffiths DT. Farm animals as a putative reservoir for vancomycin resistant enterococcal infection in man. J. Antimicrob. Chemother. 1994; 34: 507-516.

20. Teuber M. Veterinary use and antibiotic resistance. Curr Opin Microbiol 2001; 4: 493-499.

21. MilwardBrown SMG/KRC na zlecenie Narodowego Instytutu Leków; październik 2010 [cited 2016 Oct 18]. http://badania.net/18-listopada-europejskim-dniem-wiedzy-o-antybiotykach/ (in Polish). 